\title{
EKSPERIMENTASI MODEL PEMBELAJARAN KOOPERATIF TIPE STUDENT TEAMS ACHIEVEMENT DIVISIONS DAN THINK PAIR AND SHARE TERHADAP KEMAMPUAN PEMAHAMAN KONSEP MATEMATIS SISWA
}

\author{
${ }^{1}$ Intan Triasuci Apriliani \\ ${ }^{1}$ Prodi Pendidikan Matematika, Fakultas Keguruan dan Ilmu Pendidikan, Universitas Muhammadiyah Sukabumi \\ ${ }^{1}$ thriaariyansyah@gmail.com
}

\begin{abstract}
Abstrak
Penelitian ini bertujuan untuk mengetahui apakah terdapat perbedaan kemampuan pemahaman konsep matematis siswa yang memperoleh perlakuan model pembelajaran Student Teams Achievement Divisions, model pembelajaran Think Pair and Share, dan model pembelajaran Langsung, serta untuk mengetahui model pembelajaran manakah yang lebih baik dari ketiga model pembelajaran tersebut. Penelitian ini menggunakan metode kuasi eksperimen dengan desain penelitian The nonequivalent posttest only control group design. Populasi dalam penelitian ini adalah seluruh siswa kelas VII SMP Negeri 8 Kota Sukabumi tahun ajaran 2016/2017. Teknik pengumpulan data yang dilakukan dalam penelitian ini yaitu dokumentasi dan wawancara, instrumen penelitian yang digunakan yaitu lembar observasi dan metode tes. Hasil penelitian menunjukan bahwa: 1) Kemampuan pemahaman konsep matematis siswa yang memperoleh model pembelajaran STAD lebih baik daripada siswa yang memperoleh model pembelajaran TPS; 2) Kemampuan pemahaman konsep matematis siswa yang memperoleh model pembelajaran STAD lebih baik daripada siswa yang memperoleh model pembelajaran langsung.
\end{abstract}

Kata Kunci: Kemampuan pemahaman konsep matematis, model pembelajaran STAD, model pembelajaran TPS.

\section{PENDAHULUAN}

Dalam Undang Undang Dasar Republik Indonesia tahun 1945 disebutkan bahwa salah satu tujuan nasional yaitu untuk mencerdaskan kehidupan bangsa. Pencapaian untuk mewujudkan salah satu tujuan nasional tersebut yaitu melalui jalur pendidikan. Pendidikan melibatkan proses kegiatan belajar mengajar di suatu instansi pendidikan pada jenjang pendidikan dasar, pendidikan menengah, pendidikan atas hingga di perguruan tinggi. Menurut UU No.20 tahun 2003 "Pendidikan adalah usaha sadar dan terencana untuk mewujudkan suasana belajar dan proses pembelajaran agar siswa secara aktif mengembangkan potensi dirinya untuk memiliki kekuatan spiritual keagamaan, pengendalian diri, keperibadian, kecerdasan, akhlak mulia, serta keterampilan yang diperlukan dirinya, masyarakat, bangsa dan negara".

Mengingat peran pendidikan sangat berpengaruh terhadap peningkatan sumberdaya manusia yang berkualitas, matematika merupakan suatu pelajaran di sekolah yang memberi siswa dengan kemampuan berfikir logis, analitis, sistematis, kritis, dan kreatif, serta kemampuan bekerja sama (Faudzan, 2014:61). Oleh karena itu matematika perlu diajarkan pada semua jenjang pendidikan, mulai dari Sekolah Dasar sampai perguruan tinggi. Menurut Permendiknas No 22 Tahun 2006 (Yerizon, 2012: 8) salah satu tujuan matematika pada pendidikan menengah adalah agar siswa memiliki kemampuan memahami konsep matematika, menjelaskan keterkaitan antar konsep dan mengaplikasikan konsep atau algoritma, secara luwes, akurat, efisien, dan tepat dalam pemecahan masalah.

Dalam pembelajaran matematika seperti yang dinyatakan Zulkardi (Yarman dkk, 2012:20) bahwa "mata pelajaran matematika menekankan pada konsep". Artinya dalam mempelajari matematika siswa harus memahami konsep matematika terlebih dahulu agar dapat menyelesaikan soal-soal dan mampu mengaplikasikan pembelajaran tersebut di dunia nyata dan mampu mengembangkan kemampuan lain yang menjadi tujuan dari pembelajaran matematika. Pemahaman terhadap konsep-konsep matematika merupakan dasar untuk belajar matematika secara bermakna. Berkaitan dengan hal tersebut, menurut Yarman (2012:19) kemampuan pemahaman konsep matematika adalah salah satu kemampuan yang harus dimiliki siswa dan menjadi tujuan pembelajaran matematika.

Kemampuan pemahaman konsep matematis adalah kemampuan menyerap dan memahami ide-ide matematika. Pada umumnya, para ahli mengukur kemampuan pemahaman matematis melalui indikator. Menurut Kilpatrick et al. (dalam Lestari dan Yudhanegara, 2015:81) indikator pemahaman konsep matematika adalah sebagai berikut: 
a. Menyatakan ulang konsep yang telah dipelajari;

b. Mengklasifikasi objek-objek berdasarkan konsep matematika;

c. Menerapkan konsep secara alogaritma;

d. Memberikan contoh atau kontra contoh dari konsep yang dipelajari;

e. Menyajikan konsep dalam berbagai representasi;

f. Mengaitkan berbagai konsep (internal dan eksternal matematika).

Namun, pada kenyataannya kemampuan pemahaman matematis siswa Indonesia belum sepenuhnya baik. Hal ini ditunjukkan dari hasil penelitian Trends in International Mathematics and Science Study (TIMSS) 2011 yaitu suatu lembaga yang mengukur pendidikan dunia, menyatakan Indonesia menempati peringkat ke 38 dari 63 negara dalam pembelajaran matematika. Aspek yang dinilai dalam matematika adalah pengetahuan tentang fakta, prosedur, konsep, penerapan pengetahuan dan pemahaman konsep. Menurut laporan hasil studi tersebut, hanya $28 \%$ siswa Indonesia yang menjawab benar, sedangkan rata-rata internasional $47 \%$. Jika dibandingkan dengan negara lain kemampuan Indonesia dalam menerjemahkan soal ke dalam bahasa atau ide matematika diagram atau grafik ini masih berada di bawah rata-rata (TIMSS, 2011). Sementara itu, hasil laporan survei Programme for International Student Assessment (PISA) yang merupakan program organisasi kerjasama ekonomi dan pembangunan dunia (OECD) menunjukkan bahwa pada tahun 2009, prestasi siswa Indonesia berada pada posisi 68 dari 74 negara yang disurvei. Skor rata-rata kemampuan matematis siswa Indonesia yaitu 371 di bawah skor rata-rata kemampuan matematis siswa di negara lainnya yaitu 496 Aspek yang dinilai dalam PISA adalah kemampuan pemahaman, pemecahan masalah (problem solving), kemampuan penalaran (reasoning), dan kemampuan komunikasi (communication) (Gardenia, 2016:111).

Hasil TIMSS dan PISA tersebut dapat dijadikan sebagai salah satu informasi bahwa kemampuan pemahaman konsep siswa masih belum sepenuhnya baik. Rendahnya kemampuan pemahaman konsep terlihat dari kenyataan di lapangan, berdasarkan hasil wawancara pada tanggal 7 Desember 2016 bersama guru Matematika SMP Negeri 8 Kota Sukabumi, bahwa kemampuan pemahaman konsep siswa dalam pembelajaran matematika masih rendah. Hal ini terlihat dari Nilai Ulangan Tengah Semester (UTS) siswa masih mendapatkan nilai di bawah Kriteria Ketuntasan Minimum (KKM) yang ditetapkan yaitu 75,00. Dari 201 siswa kelas VII SMP N 8 kota sukabumi hanya 22 orang siswa mencapai KKM. Persentase nilai UTS dapat dilihat pada tabel berikut:
Tabel 1. Persentase Ketuntasan Belajar Siswa Pada UTS Mata Pelajaran Matematika Kelas VII SMP Negeri 8 Kota Sukabumi

\begin{tabular}{cccc}
\hline Kelas & $\begin{array}{c}\text { Jumlah } \\
\text { siswa yang } \\
\text { tuntas } \\
\text { nilai } \geq \mathbf{7 5}\end{array}$ & $\begin{array}{c}\text { Jumlah } \\
\text { seluruh } \\
\text { siswa }\end{array}$ & $\begin{array}{c}\text { Persentase } \\
\text { siswa yang } \\
\text { tuntas (\%) }\end{array}$ \\
\hline VIIA & 2 & 34 & 5,88 \\
VII B & 2 & 34 & 5,88 \\
VII C & 4 & 33 & 12,12 \\
VII D & 3 & 33 & 9,09 \\
VII E & 3 & 34 & 8,82 \\
VII F & 8 & 33 & 24,24 \\
\hline
\end{tabular}

Salah satu faktor penyebab rendahnya kemampuan pemahaman konsep matematika siswa terlihat pada saat proses pembelajaran di dalam kelas, ketika guru memberikan soal yang sedikit bervariasi dibandingkan dengan soal yang dicontohkan, siswa mengalami kesulitan dalam menyeleseaikanya, bahkan hanya beberapa siswa yang dapat menjawab dengan benar. Model pembelajaran yang digunakan di sekolah tersebut masih menggunakan model pembelajaran langsung sehingga membuat siswa menjadi kurang aktif dalam peroses pembelajaran, siswa hanya mendengarakan dan mencatat ketika guru menjelaskan.

Oleh karena itu untuk mengatasi permasalahan tersebut, perlu adanya model pembelajaran efektif yang dapat meningkatkan kemampuan pemahaman konsep matematika dan menjadikan siswa lebih aktif dalam pembelajaran. Salah satu model pembelajaran yang efektif adalah model pembelajaran kooperatif, yang tidak lagi didominasi oleh guru melainkan adanya interaksi antar guru dengan siswa. Dalam pembelajaran tersebut dibentuk kelompok-kelompok kecil dan siswa bekerja sama dengan kelompoknya untuk memecahkan permasalahan yang ada. Adapun model pembelajaran yang dimaksud ialah model pembelajaran Student Teams Achievement Division (STAD) dan Think Pair and Share (TPS) dengan menggunakan kedua model pembelajaran tersebut, diharapkan adanya perubahan pembelajaran yang berpusat pada guru menjadi berpusat pada siswa, karena kedua model pembelajaran ini lebih menekankan siswa untuk belajar berdiskusi dalam kelompok maupun berpasangan.

Model pembelajaran STAD merupakan salah satu tipe model pembelajaran kooperatif, menurut Faudzan (2014:62) "sistem pembelajaran STAD memberikan kesempatan kepada siswa untuk belajar satu sama lain untuk memastikan bahwa tiap anggota dalam kelompok telah menguasai konsep-kosep yang telah dibahas". Sama halnya dengan model pembelajaran STAD, model pembelajaran TPS merupakan salah satu model pembelajaran kooperatif, TPS adalah model pembelajaran yang dirancang untuk aktivitas siswa 
dengan belajar secara berpasangan. Zulkarnain berpendapat (2015:106) prosedur yang digunakan dalam TPS memberikan siswa lebih banyak waktu berpikir secara individu dan berpasangan untuk merespon dan saling membantu. Model pembelajaran TPS dikembangkan dalam usaha untuk meningkatkan aktifitas dan pemahaman dalam proses pembelajaran.

Kedua model pembelajaran ini sama-sama bagian dari model pembelajaran kooperatif. Pembelajaran yang dilakukan dengan cara meningkatkan aktivitas belajar bersama sejumlah peserta didik dalam satu kelompok. Aktivitas siswa menekankan untuk saling membantu mencari dan mengolah informasi, mengaplikasikan pengetahuan dan keterampilan, namun model pembelajaran STAD dan TPS memiliki perbedaan masing-masing dalam ketentuan jumlah anggota kelompoknya. Model pembelajaran STAD beranggotakan 4-5 orang siswa, sedangkan model pembelajaran TPS beranggotakan 2 orang atau secara berpasangan. Alasan peneliti menggunakan kedua model pembelajaran tersebut yaitu ingin mengetahui model pembelajaran manakah yang lebih baik antara model kooperatif tipe STAD dan TPS dilihat dari perbedaan jumlah anggota dalam kelompok. Dengan kedua model pembelajaran kooperatif tersebut maka kemampuan pemahaman matematis siswa akan terdapat perubahan dengan yang sebelumnya.

Rumusan masalah dalam penelitian ini sebagai berikut. 1) Manakah model pembelajaran yang lebih baik antara model pembelajaran STAD dan model pembelajaran TPS dalam kemampuan pemahaman konsep matematis siswa? 2) Apakah kemampuan pemahaman konsep matematika siswa yang memperoleh model pembelajaran STAD lebih baik daripada siswa yang memperoleh model pembelajaran langsung?

Tujuaan penelitian ini adalah sebagai berikut: 1) untuk mengetahi perbandingan model pembelajaran STAD dan TPS terhadap kemampuan pemahaman kosep matematis siswa; 2) Untuk mengetahui kemampuan pemahaman konsep matematika siswa yang memperoleh model pembelajaran STAD lebih baik daripada siswa yang memperoleh model pembelajaran langsung.

\section{METODE}

Metode yang digunakan dalam penelitian ini adalah metode eksperimen semu (quasi experimental). Dinyatakan Sugiyono (2014:116) quasi experimental merupakan pengembangan dari true experimental yang sulit dilaksanakan. Metode penelitian quasi experimental ini mempunyai kelompok kontrol, tetapi tidak dapat berfungsi sepenuhnya untuk mengontrol variabelvariabel luar yang mempengaruhi pelaksanaan eksperimen. Desain penelitian yang digunakan dalam penelitian ini yaitu The nonequivalent posttest only control group design. Desain penelitian dapat dituliskan sebagai berikut:

Tabel 2. Desain penelitian

\begin{tabular}{llll}
\hline Eksperimen 1 & $\mathbf{A}$ & $\mathbf{X}_{\mathbf{1}}$ & $\mathbf{O}$ \\
\hline Eksperimen 2 & $\mathrm{A}$ & $\mathrm{X}_{2}$ & $\mathrm{O}$ \\
Kontrol & $\mathrm{A}$ & $\mathrm{X}_{3}$ & $\mathrm{O}$ \\
\hline
\end{tabular}

Keterangan:

A : Sampel acak kelas

$\mathrm{X}_{1} \quad$ : Model pembelajaran STAD

$\mathrm{X}_{2} \quad$ : Model pembelajaran TPS

$\mathrm{X}_{3} \quad$ : Model pembelajaran langsung

O : Posttest

(Sugiyono, 2014:114)

Populasi dalam penelitian ini yaitu seluruh siswa kelas VII SMP Negeri 8 Kota Sukabumi tahun ajaran 2016/2017 yang terdiri dari enam kelas, jumlah keseluruhan siswa kelas VII sebanyak 201orang. Teknik pengambilan sampel yang digunakan dalam penelitian ini adalah Cluster Random Sampling. Menurut Darmawan (2013:148) cluster randomsampling yaitu pengambilan sampel seacara acak dan berumpun. Anggota sampel dalam teknik ini adalah rumpun-rumpun, kemudian dari setiap rumpun diambil rumpun kecil yang sama. Dimana dari enam kelas diambil menjadi tiga kelas, dua kelas eksperimen dan satu kelas kontrol. Cara pengambilan ketiga kelas tersebut menggunakan undian, untuk undian pertama yaitu kelas VII A sebanyak 34 orang menjadi kelas eksperimen 1 dengan perlakuan model pembelajaran STAD, undian kedua yaitu kelas VII D sebanyak 33 orang menjadi kelas eksperimen 2 dengan perlakuan model pembelajaran TPS, dan udian yang ketiga yaitu kelas VII B sebanyak 34 orang menjadi kelas kontrol dengan perlakuan model pembelajaran langsung.

Teknik pengumpulan data yang digunakan dalam penelitian ini yaitu sebagai berikut: 1) Dokumentasi; 2) Wawancara. Instrumen yang digunakan dalam penelitian ini yaitu : 1) Metode Tes; 2) Lembar observasi. Adapun langkah-langkah pada metode tes (Lestari dan Yudhanegara, 2015: 105)sebagai berikut:

a. Menentukan indikator dari variabel yang diteliti dalam penelitian;

b. Menyusun kisi-kisi instrumen;

c. Menentukan kriteria penskoran/penilaian;

d. Merumuskan item-item pertanyaan atau pernyataan;

e. Melakukan uji coba instrumen;

f. Memberikan penskoran/penilaian;

g. Melakukan analisis hasil uji coba instrument berupa uji validitas, realibilitas, daya pembeda dan tingkat kesukaran butir soal;

h. Menentukan instrument yang akan digunakan dalam penelitian.

Teknik analisis data yang digunakan yaitu menggunakan nilai UTS untuk mengetahui kemampuan 
awal siswa yaitu dengan mengunakan uji prasyarat (uji normalitas dan uji homogenitas) serta uji keseimbangan sedangkan data posttest untuk mengetahui kemampuan akhir siswa menggunakan uji prasyarat (uji normalitas dan uji homogenitas) serta uji anava satu jalur dilanjut uji pasca anava.

\section{HASIL DAN PEMBAHASAN}

\section{Deskripsi Hasil Kemampuan Awal Siswa (UTS)}

Data kemampuan awal pemahaman konsep matematis siswa diperoleh dari hasil nilai UTS siswa. Data awal ini gunanya untuk mengetahui kemampuan pemahaman konsep matematis siswa ketiga kelas yang diambil memiliki kemampuan yang sama.

Tabel 3. Rangkuman Hasil Uji Normalitas Kemampuan Awal

\begin{tabular}{cccccc}
\hline Sampel & $\mathbf{N}$ & $\mathbf{L}_{\text {hitung }}$ & $\mathbf{L}_{\text {tabel }}$ & Keputusan & Keterangan \\
\hline $\begin{array}{c}\text { Eksperimen } \\
\text { I }\end{array}$ & 34 & 0,13 & 0,152 & $\mathrm{H}_{0}$ diterima & Normal \\
$\begin{array}{c}\text { Eksperimen } \\
\text { II } \\
\text { Kontrol }\end{array}$ & 33 & 0,118 & 0,154 & $\mathrm{H}_{0}$ diterima & Normal \\
\hline
\end{tabular}

Berdasarkan tabel 4.2 hasil perhitungan yaitu untuk kelas eksperimen I diperoleh $\mathrm{L}_{\text {hitung }}=0,13$ dengan $\mathrm{L}_{\text {tabel }}=0,152$. Karena $\mathrm{L}_{\text {hitung }}<\mathrm{L}_{\text {tabel }}$, maka $\mathrm{H}_{0}$ diterima. Sehingga dapat disimpulkan bahwa kelas eksperimen I berasal dari populasi yang berdistribusi normal.Untuk kelas eksperimen II hasil perhitungan diperoleh $\mathrm{L}_{\text {hitung }}=$ 0,118 dengan $\mathrm{L}_{\text {tabel }}=0,154$. Karena $\mathrm{L}_{\text {hitung }}<\mathrm{L}_{\text {tabel }}$, maka $\mathrm{H}_{0}$ diterima. Sehingga dapat disimpulkan bahwa kelas eksperimen II berasal dari populasi yang berdistribusi normal. Sedangkan hasil perhitungan kelas kontrol diperoleh $\mathrm{L}_{\text {hitung }}=0,091$ dengan $\mathrm{L}_{\text {tabel }}=0,152$. Karena $\mathrm{L}_{\text {hitung }}<\mathrm{L}_{\text {tabel }}$, maka $\mathrm{H}_{0}$ diterima. Sehingga dapat disimpulkan bahwa kelas kontrol berasal dari populasi yang berdistribusi normal.

Tabel 4. Rangkuman Hasil Uji Homogenitas Kemampuan Awal

\begin{tabular}{ccccc}
\hline Sampel & $\mathbf{X}^{2}{ }_{\text {obs }}$ & $\mathbf{X}^{2}$ tabel & $\begin{array}{c}\text { Keputusa } \\
\mathbf{n}\end{array}$ & Keterangan \\
\hline $\begin{array}{c}\text { Eksperimen } \\
\text { I }\end{array}$ & 0,0899 & 5,991 & $\begin{array}{c}\mathrm{H}_{0} \\
\text { diterima }\end{array}$ & Homogen \\
$\begin{array}{c}\text { Eksperimen } \\
\text { II }\end{array}$ & & & & \\
Kontrol & & & & \\
\hline
\end{tabular}

Berdasarkan tabel 4 menunjukan bahwa hasil perhitungan uji homogenitas data hasil UTS siswa diperoleh $\mathrm{x}^{2}{ }_{\text {obs }}<\mathrm{x}^{2}$ tabel, yaitu $\mathrm{x}^{2}{ }_{\text {obs }}=0,0899$ dengan $x_{\text {tabel }}^{2}$ $=5,991$. Karena $0,0899<5,991$ maka $\mathrm{H}_{0}$ diterima. Sehingga dapat disimpulkan bahwa sampel berasal dari populasi bervarians homogen.

Setelah mengetahui data berdistribusi normal dan homogen maka dilakukanlah uji keseimbangan untuk mengetahui ketiga kelas tersebut mempunyai kemampuan awal yang sama. Uji keseimbangan pada penelitian ini menggunakan uji analisis varians satu jalan dengan sel tak sama karena data berdistribusi normal dan homogen. dengan taraf signifikansi $\alpha=0,05$.

Tabel 5. Uji keseimbangan Kemampuan Awal Siswa

\begin{tabular}{lcccc}
\hline \multicolumn{1}{c}{ Sampel } & Rerata & $\begin{array}{c}\text { Nilai } \\
\mathbf{F}_{\text {hitung }}\end{array}$ & $\begin{array}{c}\text { Nilai } \\
\mathbf{F}_{\text {tabel }}\end{array}$ & keputusan \\
& & & & \\
\hline Eksperimen I & 45,294 & 0,30109 & 3,09 & $\mathrm{H}_{0}$ \\
Eksperimen II & 47,2723 & & & diterima \\
Kontrol & 44,852 & & & \\
\hline
\end{tabular}

Berdasarkan tabel 5 menunjukan bahwa perhitungan dengan taraf signifikansi $\alpha=0,05$, diperoleh $\mathrm{F}_{\text {hitung }}=$ 0,30109 dengan $\mathrm{F}_{0,05 ; 2 ; 98}=3,09$. Karena $\mathrm{F}_{\text {hitung }}<\mathrm{F}_{\text {tabel }}$ sehingga $\mathrm{H}_{0}$ diterima, karena $\mathrm{H}_{0}$ diterima maka dapat disimpulkan bahwa ketiga sampel memiliki kemampuan awal yang sama sebelum diberikan perlakuan.

\section{Deskripsi Hasil Kemampuan Akhir Pemahaman} Konsep Matematis (Posttest)

Data ini didapat dari hasil posttest kemampuan pemahaman konsep matematis yang diperoleh setelah dilakukan perlakuan, untuk kelompok siswa yang belajar dengan model pembelajaran STAD, model pembelajaran TPS dan model pembelajaran langsung. Berikut ini adalah hasil rangkuman Perhitungan data hasil kemampuan akhir pemahaman konsep matematis siswa.

Tabel 6. Rangkuman Hasil Uji Normalitas Kemampuan Akhir Pemahaman Konsep Matematis

\begin{tabular}{cccccc}
\hline Sampel & $\mathbf{n}$ & $\mathbf{L}_{\text {hitung }}$ & $\mathbf{L}_{\text {tabel }}$ & Keputusan & Keterangan \\
\hline $\begin{array}{c}\text { Eksperimen } \\
\text { I }\end{array}$ & 34 & 0,131 & 0,152 & $\mathrm{H}_{0}$ diterima & Normal \\
$\begin{array}{c}\text { Eksperimen } \\
\text { II }\end{array}$ & 33 & 0,1 & 0,154 & $\mathrm{H}_{0}$ diterima & Normal \\
Kontrol & 34 & 0,15 & 0,152 & $\mathrm{H}_{0}$ diterima & Normal \\
\hline
\end{tabular}

Berdasarkan tabel 6 dapat dilihat bahwa hasil uji normalitas data pada kelas Pada eksperimen I memperoleh $\mathrm{L}_{\text {hitung }}=0,131$ dengan $\mathrm{L}_{\text {tabel }}=0,152$, karena $\mathrm{L}_{\text {hitung }}<\mathrm{L}_{\text {tabe }} 1$, maka $\mathrm{H}_{0}$ diterima. Sehingga dapat disimpulkan bahwa kelas eksperimen I berasal dari populasi yang berdistribusi normal. Untuk kelas eksperimen II hasil perhitungan diperoleh $\mathrm{L}_{\text {hitung }}=0,1$ dengan $\mathrm{L}_{\text {tabel }}=0$,154. Karena $\mathrm{L}_{\text {hitung }}<\mathrm{L}_{\text {tabel }}$, maka $\mathrm{H}_{0}$ diterima. Sehingga dapat disimpulkan bahwa kelas eksperimen II berasal dari populasi yang berdistribusi normal. Sedangkan hasil perhitungan kelas kontrol diperoleh $\mathrm{L}_{\text {hitung }}=0,15$ dengan $\mathrm{L}_{\text {tabel }}=0,152$, karena $\mathrm{L}_{\text {hitung }}$ $<\mathrm{L}_{\text {tabel }}$, maka $\mathrm{H}_{0}$ diterima. Sehingga dapat disimpulkan bahwa kelas kontrol berasal dari populasi yang berdistribusi normal.Dari tabel tersebut masing-masing $\mathrm{L}_{\text {hitung }}$ tidak melebihi $\mathrm{L}_{\text {tabel }}$ artinya bukan merupakan anggota daerah kritik, maka dari itu, keputusan yang 
diambil adalah $\mathrm{H}_{0}$ diterima untuk masing-masing sampel. Hal ini berarti masing-masing sampel berasal dari populasi berdistribusi normal. Karena ketiga kelas (eksperimen dan kontrol) berdistribusi normal, maka pengujian dilanjutkan dengan uji homogenitas varians.

Tabel 7. Rangkuman Hasil Uji Homogenitas Kemampuan Akhir Pemahaman Konsep Matematis

\begin{tabular}{ccccc}
\hline Kelas & $\boldsymbol{X}^{2}{ }_{\text {obs }}$ & $\boldsymbol{X}_{\text {tabel }}^{2}$ & Keputusan & Keterangan \\
\hline $\begin{array}{c}\text { Eksperimen } \\
\text { I }\end{array}$ & 0,460 & 5,991 & H0 diterima & Homogen \\
$\begin{array}{c}\text { Eksperimen } \\
\text { II }\end{array}$ & & & & \\
Kontrol & & & & \\
\hline
\end{tabular}

Berdasarakan tabel 7 menunjukan bahwa perhitungan uji homogenitas dari hasil posttest siswa diperoleh bahwa ketiga sampel mempunyai nilai $\mathrm{x}^{2}{ }_{\text {obs }}<\mathrm{x}^{2}$ tabel, yaitu $\mathrm{x}^{2}{ }_{\text {obs }}$ $=0,460$ dengan $x_{\text {tabel }}^{2}=5,991$. Karena $x^{2}$ obs berada diluar daerah kritis, maka $\mathrm{H}_{0}$ diterima. Sehingga dapat disimpulkan bahwa sampel berasal dari populasi bervarians homogen.

Prosedur uji hipotesis pada penelitian ini menggunakan analisis variansi satu jalan dengan sel tak sama karena data berdistribusi normal dan homogen. Hasil perhitungan analisis variansi satu jalur sel tak sama dengan taraf signifikansi 0,05 disajikan pada tabel berikut:

Tabel 8. Rangkuman Hasil Uji Anava Satu Jalan Sel Tak Sama

\begin{tabular}{cccccc}
\hline Sumber & DK & JK & RK & F $_{\text {hitung }}$ & $\mathbf{F}_{\text {tabel }}$ \\
\hline Model & 2 & 3714,29 & 1857,14 & 9,137 & 3,09 \\
Galat & 98 & 19918,45 & 203,24 & - & - \\
Total & 100 & 23632,75 & - & - & - \\
Keputusan & \multicolumn{5}{c}{$\mathrm{F}_{\text {hitung }}>\mathrm{F}_{\text {tabel }}=9,271>3,09=\mathrm{H}_{0}$ ditolak } \\
\hline
\end{tabular}

Berdasarkan tabel 8 dapat dilihat bahwa hasil uji hipotesis analisis variansi satu jalan dengan sel tak sama pada tabel diatas nilai $F_{\text {hitung }}=9,271$ melebihi $F_{\text {tabel }}=$ 3,09, sehingga dapa disimpulkan bahwa $\mathrm{H}_{0}$ ditolak atau $\mathrm{H}_{1}$ diterima, artinya terdapat perbedaan kemampuan pemahaman konsep matematis siswa untuk setiap kelas eksperimen dan kelas kontrol, karena anava hanya untuk melihat ada tidaknya perbedaan kemampuan pemahaman konsep matematis setelah perlakuan pembelajaran tertentu, maka untuk melihat pembelajaran yang lebih baik antara model pembelajaran STAD, TPS, dan pembelajaran langsung dilakukan uji lanjut pasca anava. Berikut hasil perhitunga uji lanjut pasca anava dengan sel tak sama disajikan pada tabel berikut:

Tabel 9. R angkuman Hasil Uji Lanjut Pasca Anava Satu Jalan Sel Tak Sama

\begin{tabular}{ccc}
\hline \multicolumn{3}{c}{ KOMPARASI DAN HIPOTESIS } \\
\hline Komparasi & $\mathbf{H}_{\mathbf{0}}$ & $\mathbf{H}_{\mathbf{1}}$ \\
$\boldsymbol{\mu}_{\mathrm{A}}$ vs $\boldsymbol{\mu}_{\mathrm{B}}$ & $\mu_{\mathrm{A}}=\mu_{\mathrm{B}}$ & $\mu_{\mathrm{A}} \neq \mu_{\mathrm{B}}$ \\
$\boldsymbol{\mu}_{\mathrm{A}}$ vs $\boldsymbol{\mu}_{\mathrm{C}}$ & $\mu_{\mathrm{A}}=\mu_{\mathrm{C}}$ & $\mu_{\mathrm{A}} \neq \mu_{\mathrm{C}}$ \\
\multicolumn{3}{|c}{} \\
Komparasi & $\boldsymbol{\mu}_{\mathrm{A}}$ vs $\boldsymbol{\mu}_{\mathrm{B}}$ & $\boldsymbol{\mu}_{\mathrm{A}}$ vs $\boldsymbol{\mu}_{\mathrm{C}}$ \\
$(\overline{\boldsymbol{x}} \boldsymbol{i}-\overline{\boldsymbol{x}} \boldsymbol{j})^{\mathbf{2}}$ & 82,12 & 214,53 \\
\hline
\end{tabular}

\begin{tabular}{ccc}
\hline$\frac{\mathbf{1}}{\boldsymbol{n i}}+\frac{\mathbf{1}}{\boldsymbol{n j}}$ & 0,059 & 0,058 \\
$\mathbf{R K G}$ & 203,24 & 203,24 \\
$\mathbf{F}_{\text {hitung }}$ & 6,602 & 18,28 \\
Kritis & 6,18 & 6,18 \\
Keputusan & $\mathrm{H}_{0}$ ditolak & $\mathrm{H}_{0}$ tolak \\
\hline
\end{tabular}

Keterangan

$\mu_{\mathrm{A}}$ : Model pembelajaran STAD

$\mu_{\mathrm{B}}$ : Model pembelajaran TPS

$\mu_{\mathrm{c}}$ : Model pembelajaran Langsung

Berdasarkan pada tabel 9 menunjukan bahwa pengujian hipotesis :

a. Pada $\mu_{\mathrm{A}}$ dengan $\mu_{\mathrm{B}}$ diperoleh keputusan uji $\mathrm{H}_{0}$ ditolak maka secara signifikansi ada perbedaan antara kelas eksperimen I yang memperoleh model pembelajaran STAD dengan kelas eksperimen II yang memperoleh model pembelajaran TPS, karena membandingkan $\mathrm{F}$ berada pada daerah kritis $=6,602>6,18$ yang artinya terdapat perbedaan antara $\mu_{\mathrm{A}}$ dengan $\mu_{\mathrm{B}}$, sehingga dapat disimpulkan kemampuan pemahaman konsep matematis siswa yang memperoleh model pembelajaran STAD lebik baik daripada kemampuan pemahaman konsep matematis siswa yang memperoleh model pembelajaran TPS

b. Pada $\mu_{\mathrm{A}}$ dengan $\mu_{\mathrm{C}}$ diperoleh keputusan uji $\mathrm{H}_{0}$ ditolak maka secara signifikansi ada perbedaan antara kelas eksperimen I yang memperoleh model pembelajaran STAD dengan kelas kontrol yang memperoleh model pembelajaran Langsung, karena membandingkan $\mathrm{F}$ berada pada daerah kritis $=18,28>6,18$ yang artiya terdapat perbedaan antara $\mu_{\mathrm{A}}$ dengan $\mu_{\mathrm{C}}$, sehingga dapat disimpulkan kemampuan pemahaman konsep matematis siswa yang memperoleh model pembelajaran STAD lebih baik daripada kemampuan pemahaman konsep matematis siswa yang memperoleh model pembelajaran langsung.

\section{Pembahasan}

Penelitian dilaksanakan di SMP Negeri 8 Kota Sukabumi dimulai pada tanggal 20 Maret sampai dengan 7 April 2017. Penelitian dilakukan di tiga kelas, yaitu kelas VII A, VII B, dan VII D, ketiga kelas tersebut diambil secara acak dengan pengambilan sampel Cluster Random Sampling. Pada penelitian ini proses pembelajaran dilakukan sebanyak lima kali pertemuan baik untuk kelas eksperimen I yaitu kelas VII A yang meperoleh model pembelajaran STAD, kelas eksperimen II yaitu kelas VII D yang memperoleh model pembelajaran TPS, dan kelas kontrol yaitu keas VII B yang memperoleh model pembelajaran langsung. Proses pembelajaran pada kelas eksperimen setiap pertemuanya diberikan Lembar Kegiatan Siswa (LKS). Tujuanya untuk melatih daya kemampuan pemahaman konsep matematis siswa, materi yang 
diberikan pada ketiga kelas tersebut sama yaitu aritmatika sosial, setelah diberikan perlakuan kemudia diberikan Posttest kepada kelas eksperimen dan kelas kontrol. Pemberian Posttest bertujuan untuk mengetahui kemampuan pemahaman konsep matematis siswa kelas VIIA, VII B, dan VII D, nilai tersebut dianalisis untuk menjawab hipotesis yang sudah dirumuskan dari awal. Berdasarkan hasil analisis data maka dapat disimpulkan sebagai berikut.

a. Hipotesis pertama

Berdasarkan hasil dari analisis data bahwa kemampuan pemahaman konsep matematis siswa yang memperoleh model pembelajaran STAD lebih baik daripada siswa yang memperoleh model pembelajarn TPS. Hal ini terlihat saat pemberian perlakuan didalam kelas, pada kelas eksperimen I siswa yang memperoleh model pembelajaran STAD yaitu pada model pembelajaran tersebut pembagian kelompok terdiri dari 4-5 orang siswa sehingga lebih banyak ide yang muncul. Ketika salah satu siswa mengalami kesulitan masih ada siswa lainya yang dapat memberikan solusi untuk mengatasi kesulitan tersebut, dengan demikian materi sesulit apapun dapat dipahami oleh siswa. Selain komunikasi yang baik antar siswa dalam pembelajaran kooperatif tipe STAD, prolehan skor dengan penghargaan tim dapat memotivasi siswa sehingga berpengaruh pada hasil belajar. Berbeda dengan kelas eksperimen II siswa yang memperoleh model pembelajaran TPS, pada kelas tersebut terdapat beberapa kelompok yang tidak dapat memecahkan permasalahan yang terdapat di dalam LKS yang diberikan oleh guru. Meskipun kelas tersebut juga berkelompok, tetapi anggota kelompoknya hanya terdiri dari 2 orang atau berpasangan. Oleh karena itu, dengan minimnya angggota kelompok, maka tidak banyk ide yang muncul. Sehingga menimbulkan rasa kurang percaya diri pada diri siswa.

b. Hipotesis ketiga

Berdasarkan hasil analisis data bahwa kemampuan pemahaman konsep matematis siswa yang memperoleh model pembelajarn STAD lebih baik dari siswa yang memperoleh model pembelajaran langsung. Hai ini terlihat perbedaan pada saat perlakuan pada kelas eksperimen I dan kelas kontrol, untuk kelas eksperimen I siswa yang memperoleh model pembelajaran STAD terlihat antusias saat perlakuan berlangsung, masing-masing siswa dalam kelompok dituntut untuk paham dalam setiap materi, selain itu rekongnisi atau penghargaan dapat membuat tiap siswa didalam kelompok merasa lebih termotivasi untuk meningkatkan skor kelompok masingmasing sehingga pembelajaran menjadi lebih aktif jika dibandingkan dengan pembelajaran langsung yang lebih menekankan pada pembelajaran teacher centered . Sejalan dengan pendapat Rosdiani (2012:6) bahwa model pembelajaran langsung merupakan model pembelajaran yaag berpusat pada guru dan lebih mengutamakan strategi pembelajaran efektif guna memperluas materi bahan ajar. sehingga siswa hanya menerima sajian materi dari guru dan membuat siswa menjadi kurang aktif dalam pembelajaran.

\section{PENUTUP}

\section{Simpulan}

Berdasarkan hasil analisis data dan pembahasan maka dapat ditarik kesimpulan sebagai berikut:

1. Kemampuan pemahaman konsep matematis siswa yang memperoleh model pembelajaran STAD lebih baik daripada siswa yang memperoleh model pembelajaran TPS.

2. Kemampuan pemahaman konsep matematis siswa yang memperoleh model pembelajaran STAD lebih baikdaripada siswa yang memperoleh model pembelajaran langsung.

\section{Saran}

1. Untuk peneliti lebih lanjut, sebaiknya ditindaklanjuti dengan cara mengembangkan penelitian yang sejenis tetapi dengan pokok bahsan yang berbeda. Sehingga dapat dilihat bahwa penggunaan model pembelajaran STAD dan model pembelajaran TPS ini memang sesuai untuk diterapkan pada materi pembelajaran matematika lainya.

2. Untuk penggunaan model pembelajaran TPS dikelas sebaiknya penggunaan soal LKS tidak terlalu banyak karena keterbatasan jumlah anggota kelompok yang membuat siswa lama untuk menyelesaikan soal-soal dalam LKS.

\section{DAFTAR PUSTAKA}

Darmawan, D. (2013). Metode Penelitian Kuantitatif. Bandung: PT Remaja Rosdakarya.

Faudzan, A. dkk. (2014). "Pengaruh Model Pembelajaran Kooperatif Tipe Student Teams Achievement Division (STAD) Terhadap Pemahaman Konsep Matematika Siswa Kelas VII SMPN 3 PADANG".Jurnal Pendidikan Matematika. 3, (1), 61-67.

Gardenia,N.(2016). "Peningkatan Kemampuan Pemahaman dan Komunikasi Matematis Siswa SMK 
Melalui Pembelajaran Konstruktivisme Model Needham". Jurnal Formatif. 6,(2),110-118

Lestari, K. E. dan Yudhanegara,M. R. (2015). Penelitian Pendidikan Matematika. Bandung: PT Refika Adimata.

Rodiani, D.(2012). Model Pembelajaran Langsung dalam Pendidikan Jasmani dan Kesehatan". Bandung: ALFABETA.

Sugiyono. (2014). Metode Penelitian Kuanttatif, Kualitatif, dan Kombinasi (Mixed Methodes). Bandung: ALFABETA.

Yarman, dkk. (2012). "Pemahaman Konsep Matematis dan Model Pembelajaran Quantum Teaching". Jurnal Pendidikan Matematika.1. (1).19-23.

Yerizon, dkk. (2012). "Penerapan Model Think Pair and Share Terhadap Pemahaman Konsep". Jurnal Pendidikan Matematika. 1. (1). 8-12.

Zulkarnain, I. dan Djamilah, S. (2015). "Penerapan Model Pembelajaran Think Pair and Share Terhadap Kemampuan Pemahaman Matematis Siswa Sekolah Menengah Pertama". Jurnal Pendidikan Matematika. 3, (1), 105-117. 